\title{
"Where's the bloody horse?"
}

Formation of a CIF Communications Committee has generated enough comment to suggest that it is is an overdue move. Comments also suggest a feeling that all will soon be well. But, again to judge by comments, we still do not see clear sailing ahead.

As the committee sidles up to its assignment with a few ideas for action the task, at close range, exhibits more and more alarming characteristics. We probably all knew that this was how it looked at close range but were afraid to look. However, if there is to be any real change in the forestry profession's image, credibility, or influence on public opinion, we are all going to have to take a hard, close, and open-minded look at the problem.

We can of course develop projects with good short term results. We can improve our communications techniques, make and cultivate contacts with peo- ple in the public information media, put good literature to more effective use, form shock groups for confrontations or lay smoke screens for accusations. But until we agree on what the hard core of our message will be, our troubles will not lessen dramatically.

Our position now suggests, at best, someone's description of a certain school of poets who wrote very finely about practically nothing:

"They use the snaffle and the bit alright

But where's the bloody horse?"

At worst we may not even be skilful with snaffle and bit.

Thus the main task of the committee may be to decide what we really want to say to the public. Having done that we can then concentrate on how to make good, understandable common sense.
This may sound like a pre-apology for failure but that is not the intention. We see no reason why the profession cannot mount a general, continuing and effective effort to disseminate knowledge and truth regarding forestry matters as part of its normal role. Perhaps such an effort is a matter of survival. But it must be founded on a will to act. Every section and many, if not all, members must contribute.

If we are to entertain any real hope of success there must be general agreement on what kind of horse we are all going to ride on this mission. The horse will take the form of a realistic definition of the role of the forestry profession vis-à-vis the public. Once this is agreed upon, the snaffle and bit part will be relatively easy in theory but will call for a great deal of hard work by a lot of people.

J. D. MacArthur

\section{Participation 7 is sayings}

We are all familiar with proverbs or sayings like "A rolling stone gathers no moss", or "Red sky at night, Sailors delight; Red sky in the morning, Sailors warning". For Participation 7 we invite you to concoct sayings or proverbs pertinent to forestry.

Submit your entries to The Editor, The Forestry Chronicle, 17 Elizabeth St. N., Richmond Hill, Ontario. Deadline: July 31. Offerings will appear in the October issue.
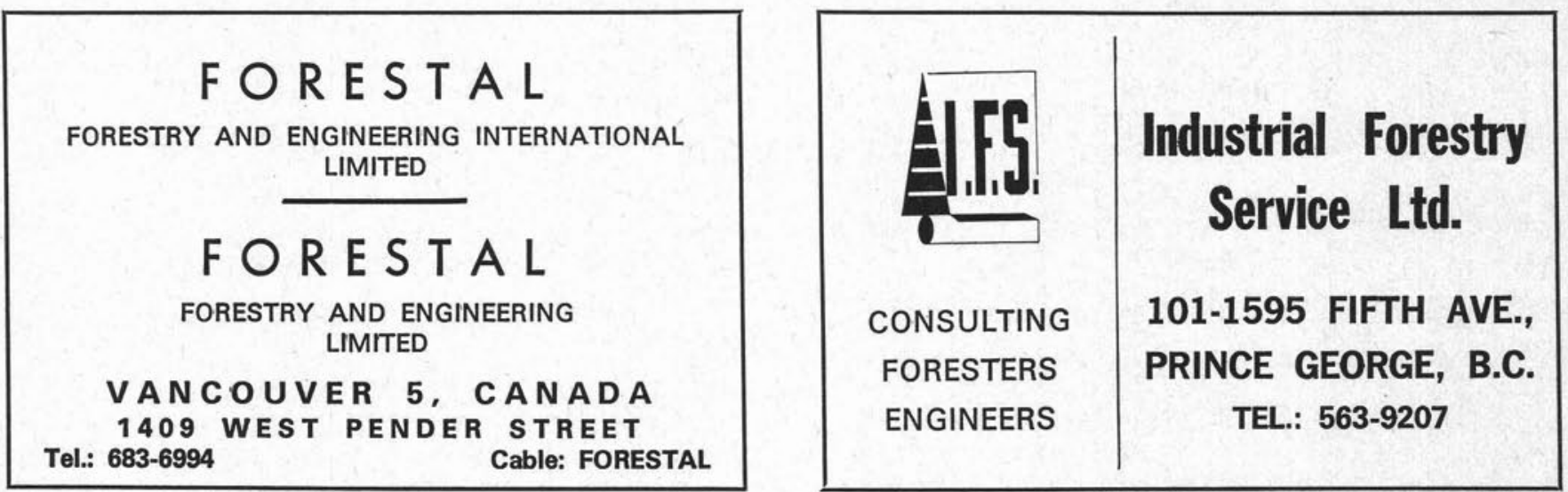